\title{
Modified Media for Heavy Metals and COD Removal from Urban Stormwater Runoff Using Pilot Bioretention Systems
}

\author{
Chunbo Jiang, Jiake Li*, Tianshun Ruan, Zhaoxin Zhang, Huaien Li \\ State Key Laboratory of Eco-hydraulics in Northwest Arid Region of China, \\ Xi'an University of Technology, Xi'an, China
}

Received: 20 June 2018

Accepted: 4 September 2018

\begin{abstract}
The media and structural optimization in bioretention systems play important roles in removing pollutants from urban stormwater runoff. Ten bioretention basins were constructed by adding water treatment residual (WTR), green zeolite, flyash, and coconut bran to traditional bioretention soil $(65 \%$ sand $+30 \%$ soil $+5 \%$ sawdust, by mass), respectively, through mixing or layering. The steady infiltration rates of modified media were 3.25 62.78 times those of plant soil. The peak flow reduction rates of plant soil (1\#) and flyash (7\#) basins were significantly high, ranging from $78.09 \%$ to $92.91 \%$ $($ median $=86.52 \%)$ and $88.01 \%$ to $96.85 \%$ (median $=93.62 \%)$. The outflow concentrations of $\mathrm{Cu}$ and $\mathrm{Zn}$ were superior to Class II limitation $\left(1.0 \mathrm{mg} \cdot \mathrm{L}^{-1}\right)$ in surface water environmental quality standards in China. The outflow concentration was inferior to Class V for COD and Cd. COD load reduction rate decreased with the increase of the recurrence interval and discharge ratio, which increased with the increase of inflow concentration. Although load reduction rate of heavy metal $\mathrm{Cd}$ increased with the increase of these three influencing factors, the reduction rate of $\mathrm{Zn}$ and $\mathrm{Cu}$ in heavy metals occurred without certain regularity. The median loading reduction rates of COD were the highest for layered media structure bioretention basins ( $6 \#$ and $8 \#)$. The heavy metal load reduction rates of $3 \# \sim 6 \#$ (mixed or layered media structure, adding 10\% WTR as modifier) and $8 \#$ (layered media structure, adding 10\% fly ash as modifier) were higher than other basins, and the median load reduction rate was mostly above $80 \%$.
\end{abstract}

Keywords: bioretention; modified media; stable infiltration rate; concentration; loading

*e-mail: xaut_ljk@163.com 


\section{Introduction}

Rainfall runoff from urban impermeable surfaces is a key polluter of urban waterways, contributing pollutants such as suspended solids (SS), biodegradable organic matter $\left(\mathrm{BOD}_{5}\right.$ and $\left.\mathrm{COD}\right)$, organic micropollutants, nutrients, and heavy metals [1-2]. Among them, heavy metals have such characteristics as persistent pollution, wide area and difficult management. Therefore, heavy metal pollution has a relatively harmful effect on the environment and the entire ecosystem, and it has become one of the hot spots.

One emerging stormwater management philosophy is low impact development (LID) [3]. LID aims to return the developed watersheds to pre-development hydrological conditions (i.e., to mimic natural water cycles or achieve hydrological neutrality) [4]. Stormwater quality regulations are another major driver for the adoption of LID, as some controls have also been implemented to improve water quality. Bioretention basins utilize soil retention to remove pollutants and allow for infiltration. However, pollutants infiltrating into soil and groundwater may cause subsurface contamination. Meanwhile, toxic metal accumulation requires periodic replacement of topsoil, making operation and maintenance more complex and costly [5]. The heavy metal purification mechanisms on urban runoff for bioretention technology often include surface media interception, limited plant absorption/uptake and internal media physical adsorption [6-7]. Studies have shown that most heavy metals are removed in the $0 \sim 20 \mathrm{~cm}$ planting soil, and the concentration of heavy metals decreases with increasing depth of the medium [8]. Zgheib et al. [9] found that the concentration of particulate $\mathrm{Pb}, \mathrm{Cd}, \mathrm{Cu}$ and $\mathrm{Zn}$ in urban storm runoff accounted for $97 \%, 83 \%, 67 \%$ and $52 \%$ of the total, respectively, and the dissolved proportions of $\mathrm{Zn}$ are highest in these four heavy metal ions. Zhao et al. [10] conducted a study on road sediments, and they found that heavy metals accounted for more than $80 \%$ of the total heavy metals in sediments sized less than $250 \mu \mathrm{m}$ in stormwater runoff, and heavy metals accounted for more than $70 \%$ in sediments whose particle size was less than $44 \mu \mathrm{m}$.

The main influencing factors of heavy metal removal by bioretention technology include rainfall runoff concentration, rainfall duration, rainfall intensity and bioretention medium types, medium height and configurations. In addition, the biological reactions would be significantly affected by the drying and wetting regimes, since the bioretention system is operated intermittently in practice [11]. Blecken et al. [12] examined the impact of this design modification on heavy metal treatment. The results show that submerged zone (SZ) and carbon source have a significant impact on metal treatment. In particular, the removal of $\mathrm{Cu}$

Table 1. Component characteristics of the media.

\begin{tabular}{|c|c|c|c|c|c|c|}
\hline No. & Media & $\rho(\mathrm{g} / \mathrm{mL})$ & BET $\left(\mathrm{m}^{2} / \mathrm{g}\right)$ & CEC $(\mathrm{cmol} / \mathrm{kg})$ & OM $(\%)$ & Porosity $\left(\mathrm{cm}^{3} / \mathrm{g}\right)$ \\
\hline 1 & Soil & 1.121 & 20.837 & 19.44 & 0.03 & 0.0300 \\
\hline 2 & BSM & 1.116 & 4.991 & 34.45 & 7.55 & 0.0096 \\
\hline 3 & WTR & 0.953 & 28.433 & 9.31 & 10.3 & 0.0215 \\
\hline 4 & Green zeolite & 1.054 & 16.871 & 27.50 & 6.98 & 0.0510 \\
\hline 5 & Flyash & 1.008 & 1.381 & 23.23 & 2.66 & 0.0066 \\
\hline 6 & Coconut bran & 0.092 & 0.811 & 13.62 & 4.65 & 0.0026 \\
\hline
\end{tabular}

Note: $\rho$ is the filling density for particles; BET is the specific surface area, $\mathrm{m}^{2} / \mathrm{g}$; CEC represents the cation exchange capacity.

Table 2. Pilot plant structure.

\begin{tabular}{|c|c|c|c|c|c|c|c|c|c|c|}
\hline No. & $1 \#$ & $2 \#$ & $3 \#$ & $4 \#$ & $5 \#$ & $6 \#$ & $7 \#$ & $8 \#$ & 9\# & $10 \#$ \\
\hline Ponding & \multicolumn{10}{|c|}{$15 \mathrm{~cm}$} \\
\hline Mulch & \multicolumn{10}{|c|}{ Pine bark $5 \mathrm{~cm}$} \\
\hline Media & $\begin{array}{c}\text { Soil } \\
70 \mathrm{~cm}\end{array}$ & $\begin{array}{c}\text { BSM } \\
70 \mathrm{~cm}\end{array}$ & $\begin{array}{l}\mathrm{BSM}+ \\
\mathrm{WTR} \\
\text { mixing } \\
70 \mathrm{~cm}\end{array}$ & $\begin{array}{l}\text { BSM + } \\
\text { WTR } \\
\text { mixing } \\
70 \mathrm{~cm}\end{array}$ & $\begin{array}{l}\mathrm{BSM}+ \\
\mathrm{WTR} \\
\text { mixing } \\
70 \mathrm{~cm}\end{array}$ & $\begin{array}{c}\text { BSM + } \\
\text { WTR } \\
\text { layering } \\
70 \mathrm{~cm}\end{array}$ & $\begin{array}{c}\mathrm{BSM}+ \\
\text { Fly ash } \\
\text { mixing } \\
70 \mathrm{~cm}\end{array}$ & $\begin{array}{c}\mathrm{BSM}+ \\
\text { Fly ash } \\
\text { layering } \\
70 \mathrm{~cm}\end{array}$ & $\begin{array}{l}\mathrm{BSM}+ \\
\mathrm{Gz} \\
\text { mixing } \\
70 \mathrm{~cm}\end{array}$ & $\begin{array}{l}\mathrm{BSM}+ \\
\mathrm{Cb} \\
\text { mixing } \\
70 \mathrm{~cm}\end{array}$ \\
\hline GDL & \multicolumn{10}{|c|}{$10 \mathrm{~cm}$} \\
\hline SZH & 0 & 0 & 0 & $150 \mathrm{~mm}$ & $350 \mathrm{~mm}$ & 0 & 0 & 0 & 0 & 0 \\
\hline
\end{tabular}

Note: SZH is the submerged zone height, $\mathrm{mm}$; GDL is the gravel drainage layer. BSM and WTR, Fly ash, Green zeolite (Gz) mixed ratio of 9: $1, \mathrm{BSM}$ and coconut bran $(\mathrm{Cb})$ mixed ratio of 19: 1 , by mass. 
was improved significantly, and $\mathrm{Zn}$ and $\mathrm{Pb}$ removal was enhanced slightly. From a quality balance standpoint, there are three measures that can be taken to improve the removal efficiency of heavy metals for bioretention facilities. Firstly, Fe or Al oxide compound could be added to the bioretention media to chelate with metal, reducing the migration rate of heavy metals. Another method is to replace shallow surface media that heavy metal accumulation saturates regularly. The other methods such as selected appropriate bioretention plants to promote the absorption of heavy metals and plants should be regularly harvested to remove heavy metals.

In this paper, the media in the bioretention systems were designed to have high metal removal potential and high permeability. 10 bioretention systems were constructed by (i) mixing efficient modifiers with traditional bioretention soil to form four modified media for bioretention and (ii) setting different configurations (i.e., layered or mixing media, different submergence area heights). These procedures were undertaken to (1) develop modified media for improving bioretention basin hydrologic performance; (2) evaluate the improvement of heavy metals and COD removal by modified media; and (3) identify the relationship between the removal effect of bioretention system and hydrologic/hydraulic elements (e.g., recurrence interval, contribution area ratio, and steady infiltration rate).

\section{Materials and Methods}

\section{Media Preparation}

Soil was collected from local topsoil using a $2 \mathrm{~mm}$ sieve. To improve soil infiltration capacity, water retention capacity, and organic quality, sand and wood chips were separately added to get traditional bioretention media (BSM). The test local river sand and soil were mixed at a ratio of 7:3 (by mass). The mixture contained $49.0 \%$ sand, $5.5 \%$ clay, and $45.5 \%$ silt; then, $5 \%$ (by mass) wood chips were added to the mixture to increase the organic content and waterholding capacity of the media. WTR, green zeolite, coconut bran, and fly ash were used as modifiers and mixed with BSM in different proportions to form modified mixed media. Fig. 1 shows the SEM images and physical photos of the media. The media characteristics were shown in Table 1, and the particle sizes were as follows: soil $(<2 \mathrm{~mm})$, zeolite $(3-6 \mathrm{~mm})$, BSM and WTR $(<6 \mathrm{~mm})$, and fly ash and coconut bran $(<1 \mathrm{~mm})$. The specific surface areas were: soil $\left(20.837 \mathrm{~m}^{2} / \mathrm{g}\right)$, BSM $\left(4.991 \mathrm{~m}^{2} / \mathrm{g}\right)$, WTR $\left(28.433 \mathrm{~m}^{2} / \mathrm{g}\right)$, green zeolite $\left(16.871 \mathrm{~m}^{2} / \mathrm{g}\right)$, flyash $\left(1.381 \mathrm{~m}^{2} / \mathrm{g}\right)$, coconut bran $\left(0.811 \mathrm{~m}^{2} / \mathrm{g}\right)$.

\section{Device Setting}

Ten pilot-scale bioretention systems were constructed in the outdoor field of Xi'an University of Technology. Each tank has the following dimensions: length $2.0 \mathrm{~m} \times$ width $0.5 \mathrm{~m} \times$ depth $1.05 \mathrm{~m}$. The construction involved $15 \mathrm{~cm}$ ponding depth, $5 \mathrm{~cm}$ mulch, $70 \mathrm{~cm}$ media, and $15 \mathrm{~cm}$ gravel layer from top to bottom. The mulch was pine bark, and Buxus sinica and Lolium perenne L. were planted. Geotextile was laid between the media and the gravel layers. A perforated drain (DN75) was placed on the bottom of the system. Each device artificial packing layer shown in Fig. 2a), 4 \#, 5 \# submerged area height (SAH) were $150 \mathrm{~mm}$ and $350 \mathrm{~mm}$, and other devices do not have an internal water storage area ( Table 2 ).

\section{Experimental Design}

Pilot-scale experiments were designed for a preexperiment, and 9 orthogonal experiments, which included the design of rainfall intensity, contribution area, inflow concentration, and submerged zone heights
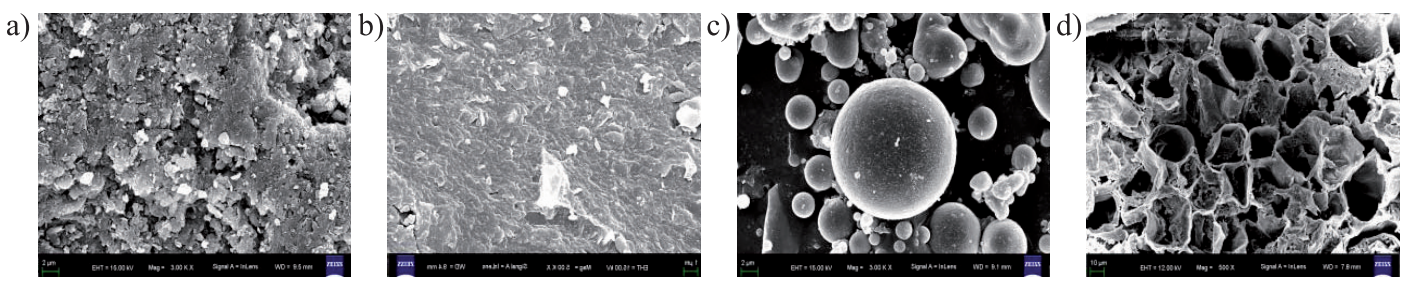

e)

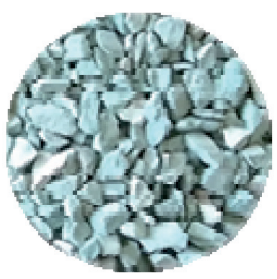

f)

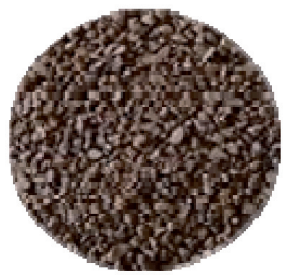

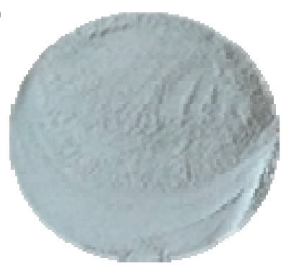

h)

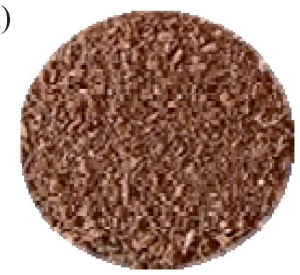

Fig. 1. Photos and SEM images of modifiers: a) Green zeolite, b) WTR, c) Flyash, d) Coconut bran, e) Green zeolite, f) WTR, g) Flyash, h) Coconut bran. 
a)

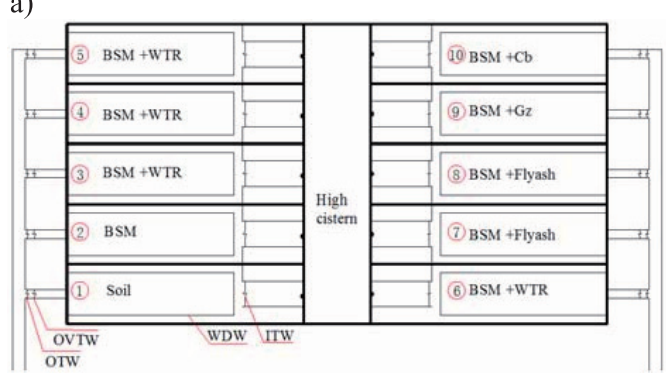

c)

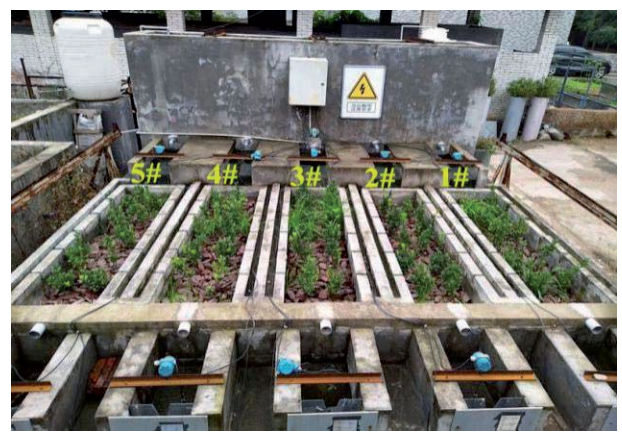

b)

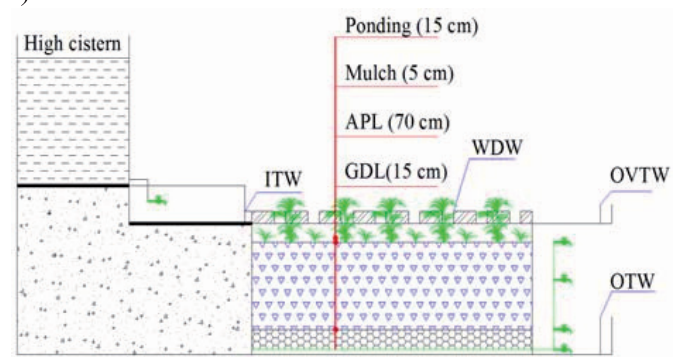

d)

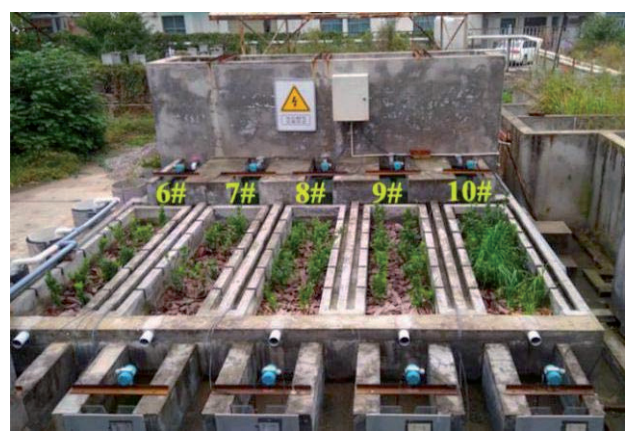

Fig. 2. Pilot plant structure and site photos: a) Floor plan, b) Sectional view, c) $1 \# \sim 5 \#$, d) $6 \# \sim 10 \#$.

Note: SZH is the submerged zone height; GDL is the gravel drainage layer. APL is artificial packing layer, ITW for inflow triangle weir, OTW for outflow triangle weir, OVTW for over triangle weir.

to determine the appropriate design parameters for the bioretention facilities. Water volume was calculated in three recurrence intervals, namely, 0.5, 2, and 3 years, and three catchment ratios (catchment area/bioretention surface area). Pollutant concentrations were determined by comparing the results of water quality assessment with urban road surface runoff in Xi'an, China. Tables 3 and 4 show the test schedule and inflow pollutant concentrations, respectively. In rainstorm design, the Pilgrim and Cordery (PC) method is insignificantly affected by rainfall duration and only increases or reduces the rain tail part when duration increases or decreases; consequently, the calculated peak flow is stable. The PC method was adopted in the rainstorm pattern calculation in the present study for the short-term rainfall data of $60 \mathrm{~min}$ from 1961 to 2014 in Xi'an [13]. $A_{1}, A_{2}$ and $A_{3}$ were $1 \mathrm{~h}$ rainfall volume under three recurrence intervals (0.5 yr, $2 \mathrm{yr}$ and $3 \mathrm{yr}$ ). $\mathrm{B}_{1}, \mathrm{~B}_{2}$ and $\mathrm{B}_{3}$ correspond to catchment ratios of $10: 1,15: 1$ and $20: 1$, respectively,

Table 3. Test schedule for the pilot-scale bioretention systems.

\begin{tabular}{|c|c|c|c|c|c|}
\hline Test number (Date) & $\begin{array}{c}\text { Precipitation/mm, } \\
\mathrm{A}_{(\text {Level } 1,2,3)}\end{array}$ & $\begin{array}{c}\mathrm{CR}, \\
\mathrm{B}_{(\text {Level } 1,2,3)}\end{array}$ & $\begin{array}{c}\mathrm{IC} /(\mathrm{mg} / \mathrm{L}), \\
\mathrm{C}_{(\mathrm{Level}, 2,3)}\end{array}$ & $\operatorname{ADT} / \mathrm{d}$ & Test conditions \\
\hline 0 & $11.47\left(\mathrm{~A}_{1}\right)$ & $10\left(\mathrm{~B}_{1}\right)$ & $6 \mathrm{~d}\left(\mathrm{C}_{1}\right)$ & $\mathrm{A}_{1} \mathrm{~B}_{1} \mathrm{C}_{1}$ \\
\hline 1 & $11.47\left(\mathrm{~A}_{1}\right)$ & $15\left(\mathrm{~B}_{2}\right)$ & $\operatorname{medium}\left(\mathrm{C}_{2}\right)$ & $6 \mathrm{~d}$ & $\mathrm{~A}_{1} \mathrm{~B}_{2} \mathrm{C}_{2}$ \\
\hline 2 & $11.47\left(\mathrm{~A}_{1}\right)$ & $20\left(\mathrm{~B}_{3}\right)$ & $\operatorname{low}\left(\mathrm{C}_{3}\right)$ & $6 \mathrm{~d}$ & $\mathrm{~A}_{1} \mathrm{~B}_{3} \mathrm{C}_{3}$ \\
\hline 3 & $23.88\left(\mathrm{~A}_{2}\right)$ & $10\left(\mathrm{~B}_{1}\right)$ & $\operatorname{medium}\left(\mathrm{C}_{2}\right)$ & $6 \mathrm{~d}$ & $\mathrm{~A}_{2} \mathrm{~B}_{1} \mathrm{C}_{2}$ \\
\hline 4 & $23.88\left(\mathrm{~A}_{2}\right)$ & $15\left(\mathrm{~B}_{2}\right)$ & $\operatorname{low}\left(\mathrm{C}_{3}\right)$ & $6 \mathrm{~d}$ & $\mathrm{~A}_{2} \mathrm{~B}_{2} \mathrm{C}_{3}$ \\
\hline 5 & $23.88\left(\mathrm{~A}_{2}\right)$ & $20\left(\mathrm{~B}_{3}\right)$ & $\operatorname{high}\left(\mathrm{C}_{1}\right)$ & $6 \mathrm{~d}$ & $\mathrm{~A}_{2} \mathrm{~B}_{3} \mathrm{C}_{1}$ \\
\hline 6 & $27.51\left(\mathrm{~A}_{3}\right)$ & $10\left(\mathrm{~B}_{1}\right)$ & $\operatorname{low}\left(\mathrm{C}_{3}\right)$ & $6 \mathrm{~d}$ & $\mathrm{~A}_{3} \mathrm{~B}_{1} \mathrm{C}_{3}$ \\
\hline 7 & $27.51\left(\mathrm{~A}_{3}\right)$ & $15\left(\mathrm{~B}_{2}\right)$ & $\operatorname{high}\left(\mathrm{C}_{1}\right)$ & $6 \mathrm{~d}$ & $\mathrm{~A}_{3} \mathrm{~B}_{2} \mathrm{C}_{1}$ \\
\hline 8 & $27.51\left(\mathrm{~A}_{3}\right)$ & $20\left(\mathrm{~B}_{3}\right)$ & $\operatorname{medium}\left(\mathrm{C}_{2}\right)$ & $6 \mathrm{~d}$ & $\mathrm{~A}_{3} \mathrm{~B}_{3} \mathrm{C}_{2}$ \\
\hline 9 & $11.47\left(\mathrm{~A}_{1}\right)$ & $10\left(\mathrm{~B}_{1}\right)$ & $\operatorname{high}\left(\mathrm{C}_{1}\right)$ & $6 \mathrm{~d}$ & $\mathrm{~A}_{1} \mathrm{~B}_{1} \mathrm{C}_{1}$ \\
\hline
\end{tabular}

Note: Catchment ratio is the catchment area/bioretention surface area; CR is catchment ratio; IC is inflow concentration; ADT is antecedent dry time 
Table 4. Concentrations of inflow pollutants $(\mathrm{mg} / \mathrm{L})$.

\begin{tabular}{|c|c|c|c|c|c|c|c|}
\hline Pollutants & COD & Copper & Zinc & Cadmium & $\mathrm{NO}_{3}-\mathrm{N}$ & $\mathrm{NH}_{3}-\mathrm{N}$ & $\mathrm{TP}$ \\
\hline High & 600 & 1.0 & 1.5 & 0.5 & 12 & 6 & 2.5 \\
\hline Medium & 300 & 0.5 & 1.0 & 0.3 & 6 & 3 & 1.5 \\
\hline Low & 100 & 0.3 & 0.5 & 0.1 & 3 & 1.5 & 1.0 \\
\hline
\end{tabular}

Note: The preparation reagents of $\mathrm{COD}, \mathrm{Cu}, \mathrm{Zn}, \mathrm{Cd}, \mathrm{NO}_{3}-\mathrm{N}, \mathrm{NH}_{3}-\mathrm{N}$ and $\mathrm{TP}$ are glucose, copper chloride, zinc sulfate, and cadmium chloride, potassium nitrate, ammonium chloride and potassium dihydrogen phosphate, respectively.

$\mathrm{C}_{1}, \mathrm{C}_{2}$, and $\mathrm{C}_{3}$ were high, medium and low design concentrations.

\section{Sampling and Analysis Methods}

The sampling was set as follows: i) inflow sampling at 0,30 , and $60 \mathrm{~min}$ after the start of the experiment; ii) overflow water sampling during overflow at 0,15 , 30, 45, and $60 \mathrm{~min}$; and iii) effluent water sampling during outflow at $0,15,30,45$, and $60 \mathrm{~min}$. The parameters for the water quality analysis were $\mathrm{pH}$, electrical conductivity, dissolved oxygen (DO), copper $(\mathrm{Cu})$, zinc $(\mathrm{Zn})$, and cadmium $(\mathrm{Cd})$. The first three parameters were used in the instrumental measurement with HACH HQ40d two-circuit input, multi-parameter numerical analysis. Water samples were filtered with a $0.45 \mu \mathrm{m}$ filterable membrane. COD was examined using HACH DRB200 digestion and UV spectrophotometry. Flame atomic absorption spectrometry (analytik jena ZEEnit 700) was performed to determine heavy metal concentrations. The measuring accuracy is $0.1 \mathrm{ug} \cdot \mathrm{L}^{-1}$, and each sample result is an average value for four times measurement.

Water reduction rate $\left(R_{\text {retention }}\right)$, peak flow cutting rate $\left(\mathrm{R}_{\mathrm{p}}\right)$, pollutant removal rate $(R)$, and load reduction rate $\left(R_{L}\right)$ were determined using Eqs. (1-4), as follows:

$$
\begin{gathered}
R_{\text {retention }}=\left(V_{\dot{n}}-V_{\text {out }}-V_{\text {over }}\right) / V_{\text {in }} \times 100 \% \\
R_{p}=\left(Q_{p-\dot{n}}-Q_{p-\text { out }}\right) / Q_{p-\dot{n}} \times 100 \% \\
R_{c}=\left(E M C_{\dot{n}}-E M C_{\text {out }}\right) / E M C_{\dot{n}} \times 100 \% \\
R_{L}=\left(L_{\dot{i}}-L_{\text {out }}-L_{\text {over }}\right) / L_{\dot{n}} \times 100 \%
\end{gathered}
$$

...where $V_{\text {in/out/over }}$ is the inflow, outflow, and overflow volume, $\mathrm{L} ; Q_{p-\text { in }}$ and $Q_{p \text {-out }}$ is inflow and outflow peak flow; $E M C_{\text {in/out }}$ is the mean concentration in a single rainfall event for inflow or outflow, $\mathrm{mg} / \mathrm{L}$; and $L_{\text {in/out } / \text { over }}$ is the inflow, outflow, and overflow pollutant load for the per test, mg.

\section{Results and Discussion}

\section{Improvement of Hydraulic Properties}

A cost-effective filter media with high COD and heavy metal sorption capacity and adequate hydraulic conductivity are the key problems in bioretention basins. Inflow volumes calculated by three recurrence

Table 5. Water regulation effect of ten bioretention basins.

\begin{tabular}{|c|c|c|c|c|}
\hline No. & $K(\mathrm{~m} / \mathrm{d})$ & $\mathrm{h}(\mathrm{cm})$ & $\mathrm{R}_{\text {retention }}(\%) \min -\max ($ median $)$ & $\mathrm{R}_{\mathrm{p}}(\%) \min -\max (\operatorname{median})$ \\
\hline 1 & 0.89 & $>15$ & $30.40 \%-51.42 \%(42.38 \%)$ & $88.01 \%-96.85 \%(93.62 \%)$ \\
\hline 2 & 12.22 & 10 & $13.24 \%-34.32 \%(24.30 \%)$ & $47.71 \%-66.05 \%(59.15 \%)$ \\
\hline 3 & 33.25 & 5 & $27.86 \%-52.15 \%(40.99 \%)$ & $58.12 \%-74.59 \%(66.52 \%)$ \\
\hline 4 & 40.32 & 2 & $16.11 \%-39.78 \%(33.08 \%)$ & $48.52 \%-71.43 \%(62.90 \%)$ \\
\hline 5 & 38.79 & 3 & $10.80 \%-54.80 \%(31.96 \%)$ & $23.74 \%-80.22 \%(56.84 \%)$ \\
\hline 6 & 20.39 & 5 & $19.30 \%-57.35 \%(34.56 \%)$ & $50.58 \%-78.15 \%(67.19 \%)$ \\
\hline 7 & 2.88 & $>15$ & $13.75 \%-56.63 \%(30.14 \%)$ & $78.09 \%-92.91 \%(86.52 \%)$ \\
\hline 8 & 4.95 & 7 & $16.32 \%-53.34 \%(27.40 \%)$ & $33.18 \%-73.71 \%(66.75 \%)$ \\
\hline 9 & 33.12 & 2 & $10.22 \%-45.15 \%(19.89 \%)$ & $32.67 \%-66.82 \%(52.82 \%)$ \\
\hline 10 & 55.75 & 0 & $13.22 \%-51.58 \%(30.91 \%)$ & $41.03 \%-71.74 \%(57.55 \%)$ \\
\hline
\end{tabular}

Note: $\mathrm{K}$ is the stable infiltration rate, $\mathrm{h}$ is the maximal ponding depth 
intervals and three catchment ratios, respectively, were simulated in this paper; meanwhile, the tests required the complete process of rainfall from the start to the end, including the "grow-peak-fall." Waterflow was smaller in the early $20 \mathrm{~min}$. Then, increases and decreases were also observed. Modifiers in the bioretention system were used to increase adsorption capacity, and sand could promote infiltration capacity [14]. Wood mulch is a common surface layer with multiple functions (e.g., moisture conservation and erosion prevention), and mulches can absorb certain metals to a degree [15-16]. Water regulation effects of 10 bioretention basins are shown in Table 5.

The implementation of bioretention facilities enables us to attenuate peak runoff, reduce combined sewer overflow to receiving water, and contribute to groundwater recharge [17]. In this study, the infiltration capacity of plant soil was relatively minimum, and the steady infiltration rate of modified filler was 3.25 62.78 times that of plant soil. The peak flow reduction rates of $1 \#$ and 7 \# bioretention basins were significantly high, ranging from $78.09 \%$ to $92.91 \%$ (median $=86.52 \%$ ) and $88.01 \%$ to $96.85 \%$ (median $=93.62 \%)$, respectively, and others are about $60 \%$. The water retention capacity of modified media was slightly lower than that of plant soil, which was $0.84 \sim 1.73$ times than that of traditional BSM. It is also possible that a side wall flow or partial preferential flow might have occurred to a certain extent, which led to a high infiltration rate. The 10 bioretention systems smoothed the hydrograph by reducing peak flow and volume for all 10 events monitored in detail. Overflow occurred in 8 events, $\mathrm{A}_{2} \mathrm{~B}_{2} \mathrm{C}_{3}, \mathrm{~A}_{2} \mathrm{~B}_{3} \mathrm{C}_{1}, \mathrm{~A}_{3} \mathrm{~B}_{1} \mathrm{C}_{3}, \mathrm{~A}_{3} \mathrm{~B}_{2} \mathrm{C}$ and $\mathrm{A}_{3} \mathrm{~B}_{3} \mathrm{C}_{2}$ for $1 \#$ bioretention basin, $\mathrm{A}_{2} \mathrm{~B}_{3} \mathrm{C}_{1}, \mathrm{~A}_{3} \mathrm{~B}_{2} \mathrm{C}_{1}$, and $\mathrm{A}_{3} \mathrm{~B}_{3} \mathrm{C}_{2}$ for $7 \#$ bioretention basin, indicating that the increased permeability did not fully compensate water regulation capacity for $7 \#$ bioretention basin. So we suggest that during the 2-yr recurrence intervals, the contribution area should be controlled below 15:1 for planted soil, and that should be controlled below 20:1 for BSM $+10 \%$ fly ash. In the 3 -yr recurrence intervals, for all the modified media no overflow occurs at the 20:1 contribution area.

\section{Heavy Metal and COD Concentration Removal Effects}

The filter media in biofiltration systems play an important role in removing potentially harmful pollutants from urban stormwater runoff. The tests compared the COD and heavy metal removal potential $(\mathrm{Cu}, \mathrm{Zn}, \mathrm{Cd})$ of 10 poilt bioretention systems that had different media or structure combinations. In addition, inflow patterns for the tests affected the water volume and peak flow control effect, and the worst media adsorption case may have appeared when the high hydraulic load comes, and the accumulated pollutants from the system may rush out during rainfall peak flows. Fig. 3 illustrated the concentration removal of pollutants, and five lines in the box from bottom to top were the minimum, under quartile, median, upper quartile, and maximum data.

Laboratory and field test results showed that bioretention basins had high purification efficiency for a)

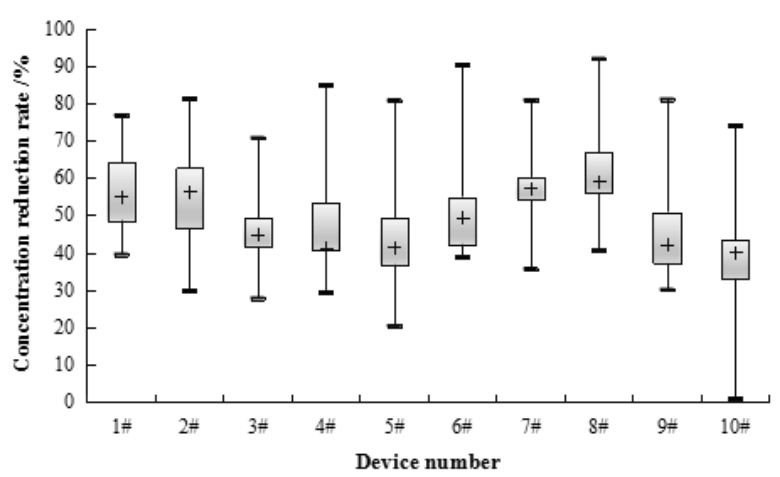

c)

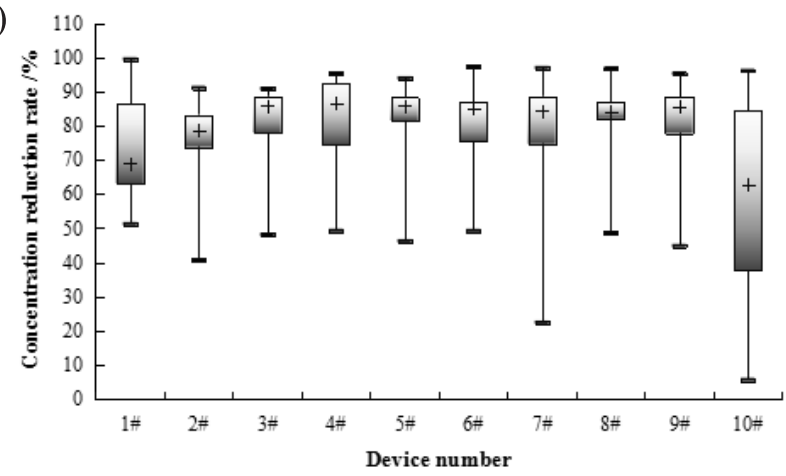

b)

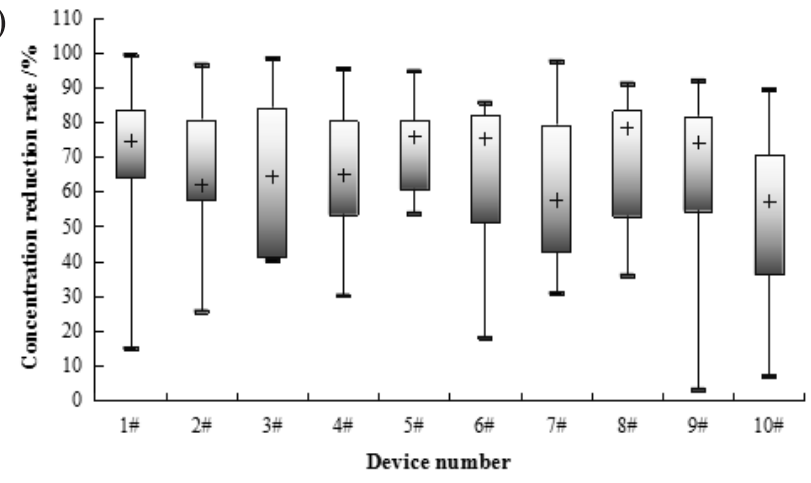

d)

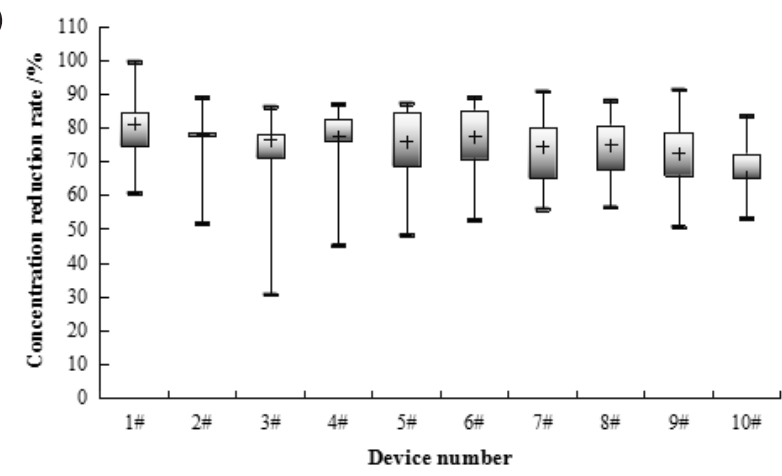

Fig. 3. Heavy metal removal in different media combinations: a) $\mathrm{COD}, \mathrm{b}) \mathrm{Cu}$, c) $\mathrm{Zn}$, d) $\mathrm{Cd}$. 
Table 6. Outflow concentrations under different conditions.

\begin{tabular}{|c|c|c|c|c|}
\hline No. & $\mathrm{C}_{\text {outflow }}-\mathrm{COD}$ & $\mathrm{C}_{\text {outflow }}-\mathrm{Cu}$ & $\mathrm{C}_{\text {outflow }}-\mathrm{Zn}$ & $\mathrm{C}_{\text {outflow }}-\mathrm{Cd}$ \\
\hline $1 \#$ & $33.63 \sim 338.12(146.01)$ & $0.007 \sim 0.368(0.173)$ & $0.001 \sim 0.698(0.207)$ & $0.002 \sim 0.127(0.056)$ \\
\hline $2 \#$ & $40.32 \sim 244.16(123.63)$ & $0.032 \sim 0.486(0.213)$ & $0.030 \sim 0.575(0.200)$ & $0.042 \sim 0.103(0.070)$ \\
\hline $3 \#$ & $52.31 \sim 327.50(160.06)$ & $0.015 \sim 0.446(0.203)$ & $0.031 \sim 0.502(0.166)$ & $0.046 \sim 0.123(0.082)$ \\
\hline $4 \#$ & $40.17 \sim 364.24(157.29)$ & $0.044 \sim 0.590(0.218)$ & $0.023 \sim 0.723(0.232)$ & $0.045 \sim 0.112(0.071)$ \\
\hline $5 \#$ & $48.94 \sim 378.40(162.57)$ & $0.050 \sim 0.493(0.180)$ & $0.018 \sim 0.522(0.183)$ & $0.043 \sim 0.112(0.074)$ \\
\hline $6 \#$ & $43.58 \sim 342.64(144.49)$ & $0.070 \sim 0.615(0.238)$ & $0.011 \sim 0.538(0.199)$ & $0.038 \sim 0.106(0.068)$ \\
\hline $7 \#$ & $38.56 \sim 256.02(120.25)$ & $0.023 \sim 0.531(0.235)$ & $0.013 \sim 0.750(0.255)$ & $0.042 \sim 0.121(0.077)$ \\
\hline $8 \#$ & $27.09 \sim 276.90(113.06)$ & $0.029 \sim 0.591(0.229)$ & $0.014 \sim 0.501(0.182)$ & $0.044 \sim 0.118(0.075)$ \\
\hline $9 \#$ & $39.45 \sim 376.88(160.44)$ & $0.026 \sim 0.632(0.253)$ & $0.012 \sim 0.645(0.238)$ & $0.039 \sim 0.129(0.080)$ \\
\hline $10 \#$ & $49.76 \sim 416.34(181.99)$ & $0.035 \sim 0.822(0.369)$ & $0.016 \sim 0.993(0.336)$ & $0.042 \sim 0.164(0.099)$ \\
\hline
\end{tabular}

Note: Values represent $\min \sim \max ($ mean $), \mathrm{mg} / \mathrm{L}$

heavy metals in stormwater runoff [18-19]. However, the different available stormwater best management practices and proprietary devices were reported to be capable of reductions of between $20 \%$ and almost $100 \%$ for both suspended solids and a range of metals [20]. The median removal efficiency of $\mathrm{COD}, \mathrm{Cu}, \mathrm{Zn}$ and Cd from 3 \# to 10 \# modified media bioretention basins were $41.36 \% \sim 59.07 \%, 57.67 \% \sim 78.48 \%, 76.03 \% \sim 88.28 \%$ and $72.36 \% \sim 77.45 \%$, respectively. The removal rate of heavy metals in 10 \# (BSM mixing coconut) was the lowest, and the removal rates of copper, zinc and cadmium were $7.04 \sim 89.35 \% \quad(57.38 \%), \quad 5.71 \sim 96.15 \%$ (62.69\%), and 7.04 89.35\% (65.29\%). Chang et al. [21] showed that there was a clear and positive correlation between the total concentration of $\mathrm{Zn}, \mathrm{Cu}, \mathrm{Cd}$, and the content of suspended particulate matter (TSS). There were no total suspended solids in the synthetic rainwater prepared in this experiment. Therefore, it did not consider the bioretention system heavy metals removal by intercepting particulate matter in stormwater runoff. The pore spaces were unevenly sized and may be connected in the column to form preferential flow pathways, and the loose structure allowed for rapid movement of water through the column, decreasing contact with the coconut material and lowering metal removal performance.

Removal mechanisms can be divided into physical, chemical and biological processes. The physical process includes filtration and retention; the chemical process include adsorption and sedimentation; and the biological process includes plant absorption and uptake, microbial removal and other biological processes. Among them, interception filtration, adsorption and precipitation play a leading role in the removal of heavy metals. The order of metal removal percentages was found as $\mathrm{Pb}>\mathrm{Cu}>\mathrm{Zn}$, and $\mathrm{Zn}$ is mainly retained via adsorption, while $\mathrm{Pb}$ and $\mathrm{Cu}$ are retained via both adsorption and filtration [22-23]. Wang et al. chose compound bioretention media composed of fine sand, zeolite, sand, quartz sand and lignin mixed in a certain proportion as the research object [24]. The results showed that heavy metal concentration, medium height and rainfall duration in rainwater runoff had little effect on the removal of heavy metals in composite bioretention media. Moreover, the dissolution process of different heavy metals in the same kind of composite medium was similar. The average values of $\mathrm{DO}$, conductivity, and $\mathrm{pH}$ were $7.6 \mathrm{mg} \cdot \mathrm{L}^{-1}$, $283.7 \mu \mathrm{s}^{\cdot} \mathrm{cm}^{-1}$, and 7.4 in these tests. Inflow concentration of other pollutants was shown in Table 3. The outflow pollutant concentration for 45 synthetic rainfall tests data were analyzed with Class II $\sim \mathrm{V}$ in environmental quality standards for surface water of China (GB38382002) taken as a benchmark (Table 6). Under the operating conditions, the effluent concentrations of $\mathrm{Cu}$ and $\mathrm{Zn}$ were less than $1.0 \mathrm{mg} \cdot \mathrm{L}^{-1}$ (Class II). Despite high removal efficiency, median concentrations of COD and $\mathrm{Cd}$ exiting, the outflow concentration is above Class $\mathrm{V}$ in surface water environmental quality standards in China, which is affected by inflow conditions (rainfall recurrence, confluence, inflow concentration) and system limitations. The standard deviation of $\mathrm{COD}, \mathrm{Cu}, \mathrm{Zn}$ and $\mathrm{Cd}$ outflow concentration were $66.59 \sim 116.99 \mathrm{mg} \cdot \mathrm{L}^{-1}$, $0.13 \sim 0.31 \mathrm{mg} \cdot \mathrm{L}^{-1}, 0.17 \sim 0.35 \mathrm{mg} \cdot \mathrm{L}^{-1}$ and $0.02 \sim 0.04 \mathrm{mg} \cdot \mathrm{L}^{-1}$, respectively, under different operating conditions. Affected by the operating conditions, the concentration of outflow pollutants in the bioretention basins were more discrete.

Pollutant Load Treatments and Hydrologic/Hydraulic Design Parameters

The treatment performance of bioretention basins relies heavily on various external factors, such as rainfall depth, duration, ADT, contribution area, etc. [25]. In this experiment ADT was 6d, and the rainfall lasted $60 \mathrm{~min}$. The main factors that influenced the 
a)

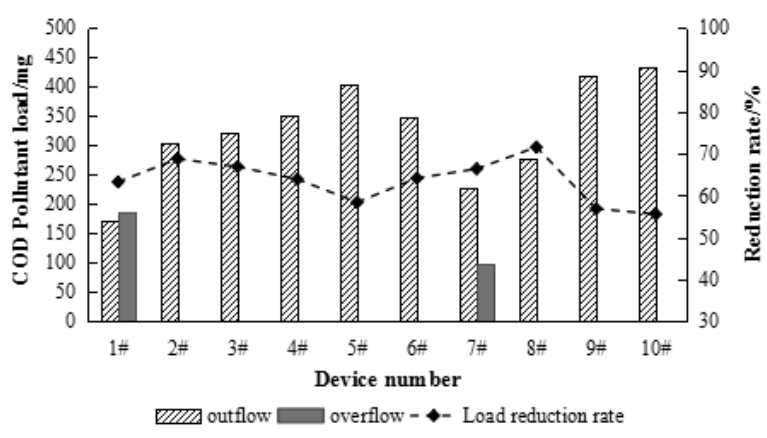

c)

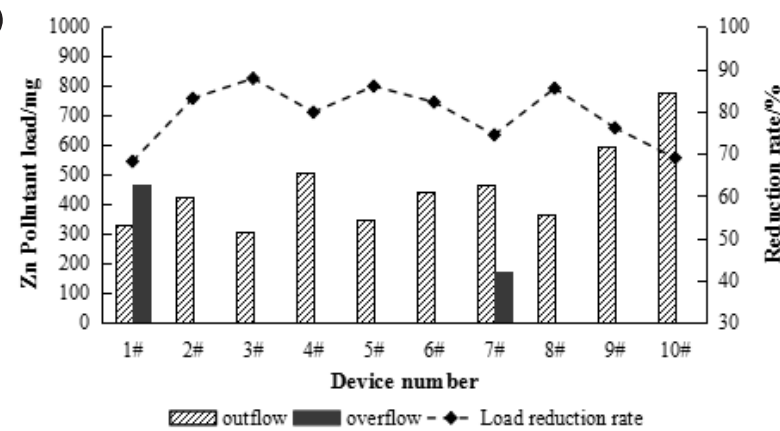

b)

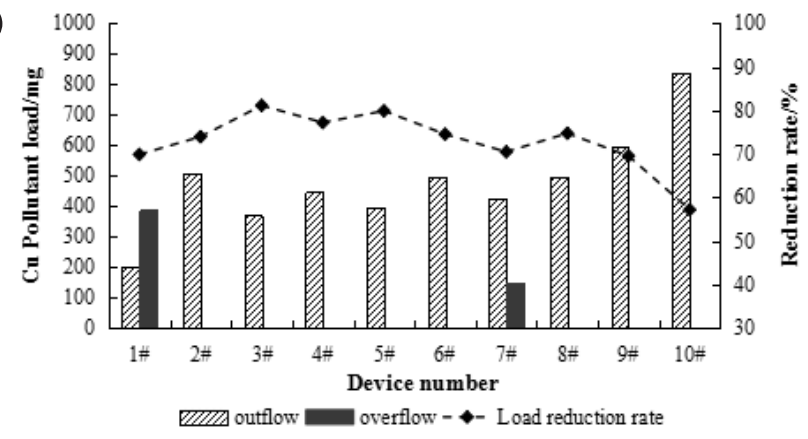

d)

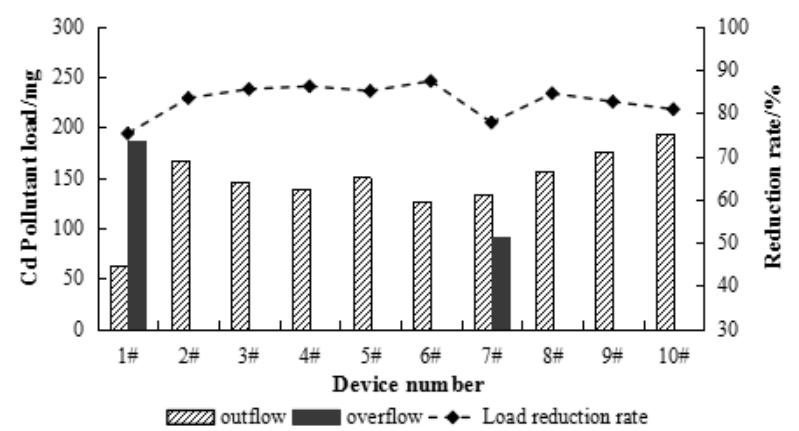

Fig. 4. Inflow/outflow loads and load reduction rates: a) $\mathrm{COD}$, b) $\mathrm{Cu}$, c) $\mathrm{Zn}$, d) $\mathrm{Cd}$.

design were rainfall recurrence interval, contribution area, and inflow concentration. In this study, the load reduction rate of bioretention systems under different design conditions fluctuated greatly. Overall, COD load reduction rate decreased with the increase of recurrence interval and discharge ratio, which increased with the increase of inflow concentration. The load reduction rate of heavy metal $\mathrm{Cd}$ increased with the increase of the recurrence interval, discharge ratio, and inflow concentration. However, the reduction rate of $\mathrm{Zn}$ and $\mathrm{Cu}$ in heavy metals was without certain regularity.

A series of bioretention tests showed that the type of media and the structure of bioretention facilities, and other internal factors, have a great effect on the purification of heavy metals [26-27]. The median loading reduction rate of $\mathrm{COD}$ was the highest for $6 \#$ and 8\#, the layered filler structure with WTR and fly ash as modifier, which were $70.98 \%$ and $75.88 \%$, respectively. 3\#, 4\#, 5\# and 6\# (mixed or layered filler structure, adding $10 \%$ WTR as modifier) and 8\# (layered filler structure with fly ash as modifier), the heavy metal load reduction rate is higher than other media, and the median load reduction rate is mostly above $80 \%$. The poor performance of coconut coir may be attributed to its porous and heterogeneous nature. One of the concerns related to heavy metal removal in bioretention systems is the limited capacity of the systems to store these metals [28]. The data from 10 simulated rainfall events of $1 \# \sim 10 \#$ bioretention systems were taken into Formula (5). The bioretention system pollutant load reduction during the test periods were obtained.

$$
R_{L(\text { total })}=\left(\sum_{i=1}^{10} L_{i \text { (inflow) }}-\sum_{i=1}^{10} L_{i(\text { outflow })}\right) / \sum_{i=1}^{10} L_{i \text { (inflow) }} \times 100 \%
$$

Research showed that dry periods reduced heavy metal uptake due to a multitude of factors, including mobilization, leaching of accumulated metals and flushing of metal-organic matter complexes upon wetting [29-30]. A one-month dry period between dosing experiments did not affect metal removal, and TOC concentrations from all materials increased after the dry period [31]. In this experiment, the interval between all rainfall events is 6 days, and the difference of running effect is only affected by its own structure and external conditions. The total inflow loads of COD, $\mathrm{Cu}, \mathrm{Zn}$ and $\mathrm{Cd}$ in the 10 simulated rainfall events were $973.410 \mathrm{~g}, 1.954 \mathrm{~g}$ and $2.502 \mathrm{~g}, 1.009 \mathrm{~g}$, respectively. The times to reach the adsorption capacities for $\mathrm{Cu}, \mathrm{Zn}$ and $\mathrm{Cd}$ were calculated under the following assumptions: media depth of $50 \mathrm{~cm}$, media composed of $30 \%$ compost and $70 \%$ sand (by volume), with a

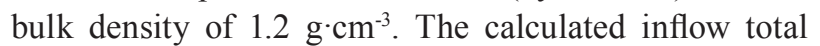
load of $\mathrm{Cu}, \mathrm{Zn}$, and $\mathrm{Cd}$ were $6.72 \mathrm{~g}, 83.52 \mathrm{~g}$ and $1.8 \mathrm{~g}$. Estimated times to reach metal adsorption capacities were $21 \mathrm{yr}, 36 \mathrm{yr}$ and $90 \mathrm{yr}$ for $\mathrm{Cu}, \mathrm{Zn}$ and $\mathrm{Cd}$, respectively [32]. The estimated system lifetimes need to depend on site-specific characteristics, including the media composition, rainfall patterns, inflow pollutant loading, and the extent of organic matter decomposition. The effluent loads were $171.25 \sim 432.08 \mathrm{~g}, 0.20 \sim 0.84 \mathrm{~g}$, $0.33 \sim 0.78 \mathrm{~g}, 0.64 \sim 0.19 \mathrm{~g}$ in this paper. All simulation rainfall results are as follows: 1\# (plant soil) outflow load is the smallest, and 10\# (BSM mixing coconut 
bran) outflow load is the largest. Overflow load of $1 \#$ bioretention system were greater than the outflow load, and $\mathrm{COD}, \mathrm{Cu}, \mathrm{Zn}$ overflow load accounted for the percentage of inflow load were: $19.12 \%, 19.80 \%, 18.57 \%$ and $18.44 \%$. 7\# (BSM mixing fly ash) bioretention overflow load is less than the outflow load, and the percentage of overflow loads of $\mathrm{COD}, \mathrm{Cu}, \mathrm{Zn}$ and $\mathrm{Cd}$ to the inflow load are, respectively, $10.11 \%, 7.73 \%, 6.85 \%$ and $9.03 \%$. There were different degrees of overflow pollution risk, and the load reduction rate is lower due to the overflow events in the $1 \#$ and $7 \#$ bioretention basins. The heavy metal load reduction in 3\# (BSM mixing WTR, without submerged area), 5\# (BSM mixing WTR, $350 \mathrm{~mm}$ submerged area) and 8\# (BSM + fly ash layering) bioretention basins were higher than others, and the $\mathrm{Cu}$ load reduction rate was greater than $75 \%$, and $\mathrm{Zn}$ and $\mathrm{Cd}$ were greater than $85 \%$.

\section{Conclusions}

The media in the bioretention system were designed to have high permeability and high metal removal potential. The steady infiltration rate of modified filler is $3.25 \sim 62.78$ times that of plant soil, and the median value of water retention capacity of modified media is $0.84 \sim 1.73$ times that of traditional BSM. The ten bioretention systems smoothed the hydrograph by reducing peak flow and volume for all 10 events monitored in detail. Overflow occurred in 8 events of $1 \#$ and $7 \#$, indicating that the increased permeability did not fully compensate water regulation capacity for $7 \#$ bioretention basins. The loose structure allowed rapid movement of water through the column, decreasing the time which the runoff contact with the media, especially for coconut material, lowering metal removal performance. The effluent concentrations of $\mathrm{Cu}$ and $\mathrm{Zn}$ were less than $1.0 \mathrm{mg} \cdot \mathrm{L}^{-1}$ (Class II) under the operating conditions, and the outflow concentrations of COD and Cd were above Class $\mathrm{V}\left(40 \mathrm{mg} \cdot \mathrm{L}^{-1}\right.$ for COD, and $0.01 \mathrm{mg} \cdot \mathrm{L}^{-1}$ for $\mathrm{Cd}$ ) in surface water environmental quality standards in China. COD and heavy metal $\mathrm{Cd}$ presents certain regularity with the recurrence interval, discharge ratio, and inflow concentration change. However, the load reduction rate of $\mathrm{Zn}$ and $\mathrm{Cu}$ under different design conditions fluctuated greatly. The COD loading reduction rate of $6 \#$ and $8 \#$ was the highest among all the media, which the layered filler structure with WTR and fly ash as modifier. 3\#, 4\#, 5\# and 6\# (mixed or layered filler structure, adding 10\% WTR as modifier) and 8\# (layered filler structure with fly ash as modifier), the heavy metal load reduction rate is higher than other media.

\section{Acknowledgements}

This research was financially supported by the Key Research and Development Project of Shaanxi Province
(2017ZDXM-SF-073) and the National Natural Science Foundation of China (51279158).

\section{Conflict of Interest}

The authors declare no conflict of interest.

\section{References}

1. CHARTERS F.J., COCHRANE T.A., O'SULLIVAN A.D. Untreated runoff quality from roof and road surfaces in a low intensity rainfall climate. Science of the Total Environment. 550, 265, 2016.

2. BARBOSA A.E., FERNANDES J.N., DAVID L.M. Key issues for sustainable urban stormwater management. Water Research. 46, 6787, 2012.

3. ECKART K., MCPHEE Z., BOLISETTI T., Performance and implementation of low impact development -A review. Science of The Total Environment. 607-608, 413, 2017.

4. DAMODARAM C., ZECHMAN E.M. Simulationoptimization approach to design low impact development for managing peak flow alterations in urbanizing watersheds. Journal of Water Resources Planning and Management. 139, 290, 2013.

5. SOLEIMANIFAR H., DENG Y., WU L.Y.,SARKAR D. Water treatment residual (WTR)-coated wood mulch for alleviation of toxic metals and phosphorus from polluted urban stormwater runoff. Chemosphere. 154, 289, 2016.

6. SUD, D., MAHAJAN G., KAUR M.P. Agriculture waste material as potential adsorbent for sequestering heavy metal ions from aqueous solutions-a review. Bioresour. Technol. 99, 6017, 2008.

7. TEDOLDI D., CHEBBO G., PIERLOT D. Impact of runoff infiltration on contaminant accumulation and transport in the soil/filter media of Sustainable Urban Drainage Systems: A literature review. Science of the Total Environment, 569, 904, 2016.

8. YANG L.Q. Heavy metal removal mechanism and risk assessment through bioretention technology. Beijing University of Civil Engineering and Architecture. 2011.

9. ZGHEIB S., MOILlERON R., SAAD M., CHEBBO G. Partition of pollution between dissolved and particulate phases: What about emerging substances in urban stormwater catchments? Water Research. 45, 913, 2011.

10. ZHAO H.T., LI X.Y., WANG X.M., TIAN D. Grain size distribution of road-deposited sediment and its contribution to heavy metal pollution in urban runoff in Beijing, China. Journal of Hazardous Materials, 183, 203, 2010.

11. HATT B.E., FLETCHER T.D., DELETIC A. Hydraulic and pollutant removal performance of fine media stormwater filtration systems. Environmental Science \& Technology. 42, 2535, 2008.

12. BLECKEN G.T., ZINGER Y., DELETIC A., FLETCHER T.D., VIKLANDER M. Influence of intermittent wetting and drying conditions on heavy metal removal by stormwater biofilters. Water Research. 43, 4590, 2009.

13. ZHOU J.M. 2015 Study on the changes in rainfall patterns in Xi'an. Xi'an: Xi'an University of Architecture \& Technology. 2015 [In Chinese].

14. O'REILLY A.M., WANIELISTA M.P., CHANG, N.B., XUN Z., HARRIS W.G. Nutrient removal using 
biosorption activated media: Preliminary biogeochemical assessment of an innovative stormwater infiltration basin. Science of the Total Environment. 432, 227, 2012.

15. SOLEIMANIFAR H., DENG Y., WU L., SARKAR D. Water treatment residual (WTR)-coated wood mulch for alleviation of toxic metals and phosphorus from polluted urban stormwater runoff. Chemosphere, 154, 289, 2016.

16. TANG N., LI T. Nitrogen removal by three types of bioretention columns under wetting and drying regimes. J. Central South Univ., 23, 1, 2016.

17. DAVIS A.P., TRAVER R.G., HUNT W.F., LEE R., BROWN R.A., OLSZEWSKI J.M. Hydrologic performance of bioretention storm-water control measures. Journal of Hydrologic Engineering. 17, 604, 2012.

18. FASSMAN E. Stormwater BMP treatment performance variability for sediment and heavy metals. Separation and Purification Technology. 84, 95, 2012.

19. SIMCOCK B., TROWSDALE S.A. Urban stormwater treatment using bioretention. Journal of Hydrology. 397, 167, 2011.

20. REVITTD M., LUNDY L., COULON F., FAIRLEY M. The sources, impact and management of car park runoff pollution: A review. Journal of Environmental Management. 146, 552, 2014.

21. CHANG J., LIU M., LIX. H., YU J., LIN X., WANG L.L., GAO L. Dissolved-particulate partitioning of heavy metals in urban road runoff of Shanghai. Advance in Water Science. 20, 714, 2009 [In Chinese].

22. JALALI M., MORADI F. Competitive sorption of $\mathrm{Cd}, \mathrm{Cu}$, $\mathrm{Mn}, \mathrm{Ni}, \mathrm{Pb}$ and $\mathrm{Zn}$ in polluted and unpolluted calcareous soils. Environ Monit Assess, 185, 8831, 2013.

23. GÜLBAZ S., KAZEZY1LMAZ-ALHAN C.M., COPY N.K. Evaluation of Heavy Metal Removal Capacity of Bioretention Systems. Water Air and Soil Pollution. 226, 376, 2015.

24. WANG J.L., YANG L.Q., HUANG T. Effect of composite bioretention media on heavy metals removal from urban stormwater runoff. Chinese Journal of Environmental Engineering. 9, 3086, 2015 [In Chinese].

25. HUBER M., WELKER A., HELMREICH B. Critical review of heavy metal pollution of traffic area runoff: Occurrence, influencing factors, and partitioning. Science of the Total Environment. 541, 895, 2016.

26. DEBUSK K.M., WYNN T.M. Stormwater bioretention for runoff quality and quantity mitigation. Journal of Environmental Engineering. 137, 800, 2011.

27. LEFEVRE G.H., PAUS K.H., NATARAJAN P., GULLIVER J.S., NOVAK P.J., HOZALSKI R.M. Review of dissolved pollutants in urban storm water and their removal and fate in bioretention cells. Journal of Environmental Engineering. 141, 1, 2015.

28. ROY-POIRIER A., CHAMPAGNE P., FILION Y. Review of bioretention system research and design: past, present, and future. Journal of Environmental Engineering. 136, 878, 2010.

29. DAVIS B., BIRCH G. Comparison of heavy metal loads in stormwater runoff from major and minor urban roads using pollutant yield rating curves. Environmental Pollution. 158, 2541, 2010.

30. REVITT D.M., LUNDY L., COULON F. FAIRLEY M. The sources, impact and management of car park runoff pollution:A review. Journal of Environmental Management. 146, 552, 2014.

31. LIM H.S., LIM W., HU J.Y., ZIEGLER A., ONG S.L. Comparison of filter media materials for heavy metal removal from urban stormwater runoff using biofiltration systems. Journal of Environmental Management. 147, 24, 2015.

32. LEFEVRE G.H., PAUS K., NATARAJAN P., GULLIVER J.C., NOVAK P.J., HOZALSKI R. Review of Dissolved Pollutants in Urban Storm Water and Their Removal and Fate in Bioretention Cells. Journal of Environmental Engineering. 141, 1, 2015. 